https://doi.org/10.15407/ufm.22.01.058

\author{
O.V. MOVCHAN and K.O. CHORNOIVANENKO* \\ National Metallurgical Academy of Ukraine, \\ 4 Gagarin Av., UA-49600 Dnipro, Ukraine \\ * ekatmovchan@gmail.com
}

\title{
IN SITU COMPOSITES: A REVIEW
}

The review of the works on the fabrication-technology studies, patterns of structure formation, and properties of in situ composites is presented. The main advantage of in situ (natural) composites is the thermodynamic stability of their composition and the coherence (conjugation) of the lattices of the contacting phases. All these ones provide the composite with a high level of the physical and mechanical properties. As shown, composite materials of this type are formed in the process of directed phase transformations, such as eutectic crystallization, eutectoid decomposition, etc., caused by a temperature gradient, as well as a result of diffusional changes in composition. The conditions for the growth of in situ composites are formulated. The mechanisms of growth of composite structures of the eutectic type are considered. The factors influencing on the morphology of structures of the eutectic type are indicated. The considered technological methods make it possible to obtain materials with predetermined properties, in which the size, volumetric composition, and spatial arrangement of phases are characteristic of in situ composites. The paper provides a large number of examples of in situ composites: from low-melting Bi-based alloys to refractory eutectics based on $\mathrm{Mo}$ and $\mathrm{W}(\mathrm{Bi}-\mathrm{MnBi}, \mathrm{Cd}-\mathrm{Zn}, \mathrm{Al}-$ $\mathrm{Al}_{3} \mathrm{Ni}, \mathrm{Al}-\mathrm{Al}_{4} \mathrm{La}, \mathrm{Al}-\mathrm{Al}_{10} \mathrm{CaFe}_{2}, \mathrm{Al}-\mathrm{Al}_{9} \mathrm{FeNi}, \mathrm{Al}-\mathrm{Al}_{3} \mathrm{Zr}, \mathrm{Al}-\mathrm{Al}_{3} \mathrm{Sc}, \mathrm{Au}-\mathrm{Co}, \mathrm{Si}-\mathrm{TaSi}_{2}$, $\mathrm{Cr}-\mathrm{HfC}, \mathrm{Cr}-\mathrm{ZrC}, \mathrm{Cr}-\mathrm{NbC}, \mathrm{Cr}-\mathrm{NbC}, \mathrm{Cr}-\mathrm{TaC}, \mathrm{Nb}-\mathrm{Nb}_{5} \mathrm{Si}_{3}, \mathrm{Mo}-\mathrm{ZrC}, \mathrm{Mo}-\mathrm{HfC}, \mathrm{W}-\mathrm{TiC}$, $\mathrm{W}-\mathrm{ZrC}, \mathrm{W}-\mathrm{HfC}$, etc.). Processes and aspects of structure formation are considered. The influence of additional doping on the structure and properties of composite materials of the eutectic type of binary systems, as well as the features of the structure formation of ternary colonies in the composite are considered.

Keywords: composite, eutectic, directional solidification, diffusion change in composition, structure formation.

Citation: O.V. Movchan and K.O. Chornoivanenko, In situ Composites: A Review, Progress in Physics of Metals, 22, No. 1: 58-77 (2021) 


\section{Introduction}

Nowadays, both the processing machinery and the auxiliary production equipment often need to operate under increasingly challenging conditions. As a result, the processed materials need to have high strength, high hardness, as well as high plasticity, high toughness, and excellent wear resistance. This one means that monolithic metallic materials are unlikely to meet these requirements [1-3]. Ceramic materials (carbides, oxides, nitrides, etc.) have high strength, excellent high-temperature oxidation resistance and wear resistance. However, they are not very tough [4-6]. Creation of materials with predefined properties is a trend in modern materials science. The developed materials should provide excellent comprehensive mechanical properties, including high strength, high toughness, high hardness and excellent wear resistance in conjunction with excellent plasticity and impact strength. Composite materials, which obtained a conditional mathematical expression: $1+1>2$, meet all these wide ranges of increased requirements. This mathematical expression indicates the combination of the positive properties of the original components to obtain material with synergistic effect exceeding the total effect. This fact has provided an ever-increasing interest in composite materials [7].

The in situ composite material is produced in one-step from an appropriate starting alloy, thus avoiding the difficulties inherent in combining the separate components as in a typical composite processing. Controlled unidirectional solidification of a eutectic alloy is a classic example of in situ processing. Eutectics are the multi-phase composites formed during liquid phase solidification processes. Both the ordered eutectics and the disordered eutectics are prepared by different methods and involve using metallic, oxide and non-oxide systems [8-19]. The synthesis of eutectic composites in situ during melt solidification provides the advantage that the resulting structures are not dependent on the properties of the starting materials such as particle size or shape but are instead related to the solidification conditions. These aligned composites exhibit enhanced bonding between phases as a direct result of the in situ growth process. Unidirectional solidification of a eutectic alloy can result in one phase being distributed in the form of fibres or ribbon in the other. One can control the fineness of distribution of the reinforcement phase by simply controlling the solidification rate. The solidification rate in practice, however, is limited to a range of 1-5 $\mathrm{cm} / \mathrm{h}$ because of the need to maintain a stable growth front [20]. The stable growth front requires a high temperature gradient.

To achieve this feature in eutectic alloys, it is involved directional solidification, which transforms the liquid alloy into two distinctly different phases: a rod or filament-like eutectic phase dispersed in a solid 


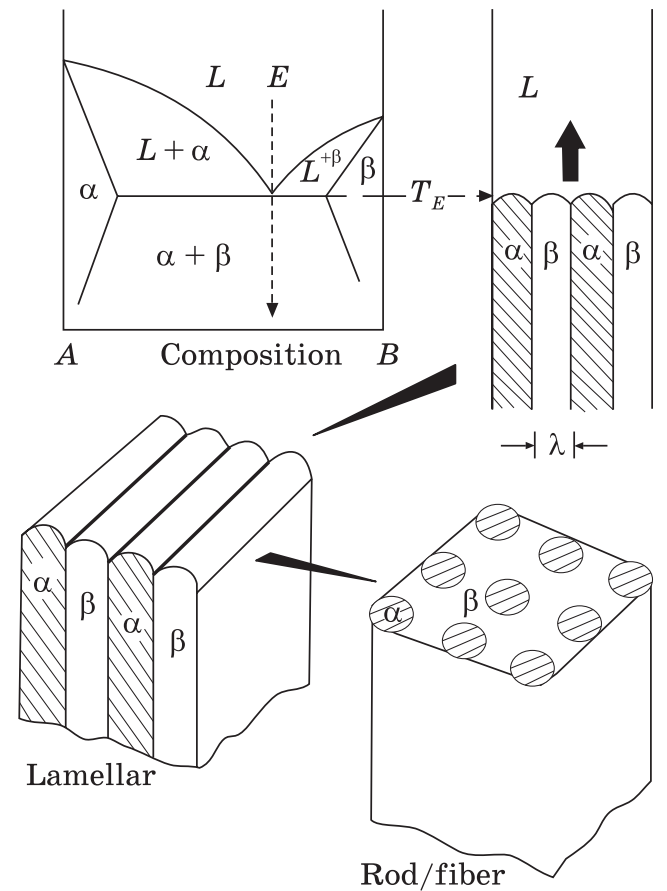

Fig. 1. Schematic phase diagram showing eutectic transformation [21]

matrix or a solid-solution matrix involving a binary composition different from the eutectic phase composition as illustrated in Fig. 1 [21]. In the fabrication of eutectic-reinforced matrix composites, the unidirectional solidification of an alloy ingot of eutectic composition is achieved under a steep axial thermal gradient by gradual withdrawal of an ingot from a furnace. This one establishes a planar solidliquid interface separating the liquid (melt) and solid phases shown by the large directional arrow in the liquid $(L)$ in Fig. 1 (upper left). The two solid phases ( $\alpha$ and $\beta$ ) produced from the eutectic reaction at the eutectic temperature ( $T_{E}$ in Fig. 1) grow parallel to the direction of solidification (large arrow in Fig. 1).

Hertzberg [22] has illustrated that the type of morphology developed in a eutectic microstructure depends on the relative volume fraction of each phase. Eutectic rods or filaments embedded in a matrix phase will form when one phase is less than that $1 / \pi$ of the total alloy volume. These features are illustrated in Fig. 1.

\section{Features of Eutectic Growth}

The coupled growth behaviour and periodic array characteristics in many eutectic systems have received considerable theoretical and experimental attention [23-27]. Although eutectic growth has been examined for many years, the most significant one of the eutectic growth theories is the Jackson and Hunt $(\mathrm{J}-\mathrm{H})$ model [28]. The J-H model, which is calculated by Eq. (1) and schematically shown in Fig. 2, gives the relationship between the interface undercooling $\Delta T$, the growth rate $V$, and the eutectic spacing $\lambda$ :

$$
\Delta T=K_{1} V \lambda+\frac{K_{2}}{\lambda}
$$

where $V$ is the growth rate; $K_{1}$ and $K_{2}$ are constant parameters and can be calculated from phase diagram and thermodynamic data for a given system. 
Fig. 2. Schematic plot of undercooling $\Delta T$ $v s$. eutectic spacing for a given growth rate $V[29]$

According to the minimum undercooling criterion, we shall denote these theoretical values of the extremum and the maximum stable spacings by $\lambda_{\text {ext }}$ and $\lambda_{\text {max }}$, respectively. As is indicated in Fig. 2, the smallest stable spacing, $\lambda_{\text {ext }}$, corre-

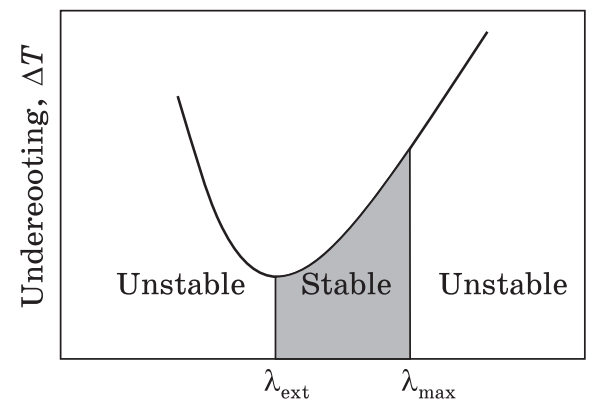

Eutectic spacing, $\lambda$ sponds to that of the minimum undercooling value, and the maximum stable spacing, $\lambda_{\max }$, corresponds to the critical spacing that appears when the larger volume fraction phase develops a depression at the centre of its lamellae. Thus, when lamellar spacings are smaller than the extremum spacing $\lambda_{\text {ext }}$, the growth will be unstable; when lamellar spacings become larger than the maximum spacing $\lambda_{\max }$, tip splitting occurs. Consequently, the eutectic growth at constant growth rate occurs within a small range of spacing values. This notion was observed by many experimental studies on eutectic spacing selection in several alloy systems, and the average spacing was found to be near but slightly larger than the extremum spacing [30-34].

Many investigations on eutectic spacing have been performed on lamellar eutectics in thin samples of metals or transparent materials at lower growth rates. Although these experiments have provided valuable information, it has also been recognized that microstructural features can also be influenced by the thickness of the samples [35]. In contrast to lamellar eutectics, there is little information on the rod-like eutectic spacing selection at high growth rates. In addition, rod eutectic morphologies are fundamentally more complex than their lamellar counterparts, since the three-dimensionality of the rod array gives rise to more diverse variation in the microstructure [36].

The solidification of off-eutectic compositions in binary, ternary, and higher-order alloy systems, concluding that under appropriate growth conditions any multiphase alloy composition could be directionally solidified to produce an aligned composite with a eutectic-like microstructure [37]. An approximate formulation of this approach leads to the experimental requirement for composite growth of

$$
\frac{G}{V}>\frac{\Delta T}{D}
$$

where $G$ is the temperature gradient, $D$ is the diffusion coefficient, and $\Delta T$ is the temperature range between start and completion of solidification of the particular alloy. (Note, in the simple binary system in 
Fig. 1, that $\Delta T$ is zero at $C_{E}$ and increases monotonically as composition departs from $C_{E}$ ).

This ability to depart from precise eutectic compositions is extremely important from the technological point of view, as it allows the addition of various alloying elements to improve specific properties, such as strength or oxidation resistance. As discussed later, this alloy ability has played an important part in the development of promising high temperature composites. The search for technologically promising alloys has led more and more into ternary, quaternary, and higher-order systems, for which phase diagram information is far less complete than for binary systems. The phase equilibrium diagram is a smart approach to the development of alloys with desired properties.

A possible increase in the performance characteristics of composites is largely determined by an understanding of the internal physical processes occurring both in the matrix and strengthening phases and at the interphase boundaries during the solidification of alloys [38]. The requirements of composite technology, which makes it possible to control the size, volumetric content, and spatial arrangement of phases, which is characteristic of in situ composites, point with particular urgency to the need to solve the problem of the forms of conjugate growth of phases. Recently, solutions have been obtained to the problem of diffusion processes on the interface between the matrix and the second phase. It also became possible to fairly accurately describe the growth of eutectic structures that limited by volume diffusion [39]. In these works, it was assumed that growth occurs under extreme conditions, for example, the maximum growth rate at a given undercooling, etc. [40]. Until now, reliable experimental data have not been obtained demonstrating a microimage of such crystallization, in which the second phase of the eutectic in the form of spheroids or other compact particles arises as a result of multiple repetitions of nucleation events at the front or in front of the crystallization front of the matrix phase [38, 41, 42]. At the same time, this is quite understandable given the fact that any thin differentiated, i.e., a typically eutectic structure with a regular or irregular structure arises during the growth of bicrystalline eutectic colonies.

Interest in eutectic composites is associated primarily with the fact that the process of obtaining them is a one-step. The possibilities for controlling such microstructure parameters as the morphology of phases, their dispersion, and mutual orientation are quite wide. Furthermore, the microstructure of eutectic composites has high thermal stability - prolonged annealing at temperatures up to $0.98 T_{E}$ (where $T_{E}$ is the melting point of the eutectic) does not lead to noticeable spheroidization or destruction of phase components (fibres, plates) [43]. Modern mechanical engineering requires alloys with high characteristics of heat resistance, hot strength, wear resistance, capable to work at tempera- 
tures above $1300 \mathrm{~K}$. One of the possibilities for obtaining such materials is the use of eutectic alloys of transition metals with interstitial phases as their basis, e.g., with carbides of high-melting-point metals IV(A)$\mathrm{V}(\mathrm{A})$ of the subgroup of the periodic table with high values of free energy of formation, melting point, hardness, modulus of elasticity, and inert to the metal-based alloy [44]. The structure of such eutectic alloys provides them the properties of a natural composite, in which the metal base is reinforced with dispersed carbide crystals. The dimensions of carbides, as a rule, do not exceed 1 micron with a large ratio of the length to the thickness of the hardening crystals. The metal base of the alloy evenly distributes the perceived load on the carbide crystals and gives it plasticity. Carbide crystals create resistance to dislocation movement in the bulk of the eutectic grain, providing compositional strengthening. The main link in the research preceding the development of the composition of the eutectic alloy is a three-component system, including a base metal, carbon and a metal that forms refractory carbide.

\section{Systems at Issue}

There is a large number of eutectic systems in which the processes of structure formation were studied - from low-melting-point alloys based on bismuth, to refractory eutectics based on molybdenum and tantalum (Bi-MnBi, $\mathrm{Pb}-\mathrm{Sn}, \mathrm{Al}-\mathrm{Al}_{3} \mathrm{Ni}, \mathrm{Al}-\mathrm{Be}, \mathrm{Al}-\mathrm{Al}_{2} \mathrm{Cu}, \mathrm{Al}-\mathrm{Si}, \mathrm{PbTe}-\mathrm{Co}, \mathrm{Cu}-\mathrm{Cr}$, $\mathrm{Cu}-\mathrm{CuZr}, \mathrm{Fe}-\mathrm{Fe}_{2} \mathrm{Nb}, \mathrm{Fe}-\mathrm{Fe}_{2} \mathrm{Zr}, \mathrm{Co}-\mathrm{Co}_{3} \mathrm{Si}, \mathrm{Co}-\mathrm{Co}_{2} \mathrm{Si}, \mathrm{Co}-\mathrm{CoAl}, \mathrm{Ni}{ }_{3} \mathrm{Al}-$ $\mathrm{Ni}_{3} \mathrm{Nb}, \mathrm{NiAl}-\mathrm{Cr}, \mathrm{Ni}-\mathrm{NbC}, \mathrm{Ni}-\mathrm{Ni}{ }_{3} \mathrm{~B}, \mathrm{Co}-\mathrm{NbC}, \mathrm{Nb}-\mathrm{Nb}_{2} \mathrm{C}, \mathrm{Ta}-\mathrm{Ta}_{2} \mathrm{C}, \mathrm{Mo}-$ $\mathrm{ZrC}$, etc.). In this case, the directional crystallization, electron-beam zone recrystallization, and various modifications of these methods were used. The study of a wide range of systems of various types (metal-metal, metal-semiconductor, metal-intermetallic, and intermetallic-intermetallic) made it possible to establish some general laws of the formation of the composite structure [45]. Thus, connection between interfibre (or interplatelet) distance $\lambda$ (Fig. 1) and crystallization rate $V$ in all systems is satisfactorily described by the expression:

$$
n=A V^{-n} \text {, }
$$

where the parameter $n$ for the different eutectics varies from $1 / 3$ to $1 / 2$ [46]. In theory [47], the value $n=1 / 2$ corresponds to the redistribution of components ahead of the crystallization front by volume diffusion, and $n=1 / 3$ - to boundary diffusion at the decay front (for example, during eutectoid transformation).

The parameter $n$ with decreasing of $V$ and a high temperature gradient at the crystallization front changed from $1 / 2$ to $1 / 3$ in some systems (particular in the $\mathrm{Co}-\mathrm{Co}_{3} \mathrm{Si}$ and $\mathrm{Cu}-\mathrm{Cr}$ eutectics) $[46,48]$. The reason for the deviation of the parameter $n$ from the value $1 / 2$ given by the 

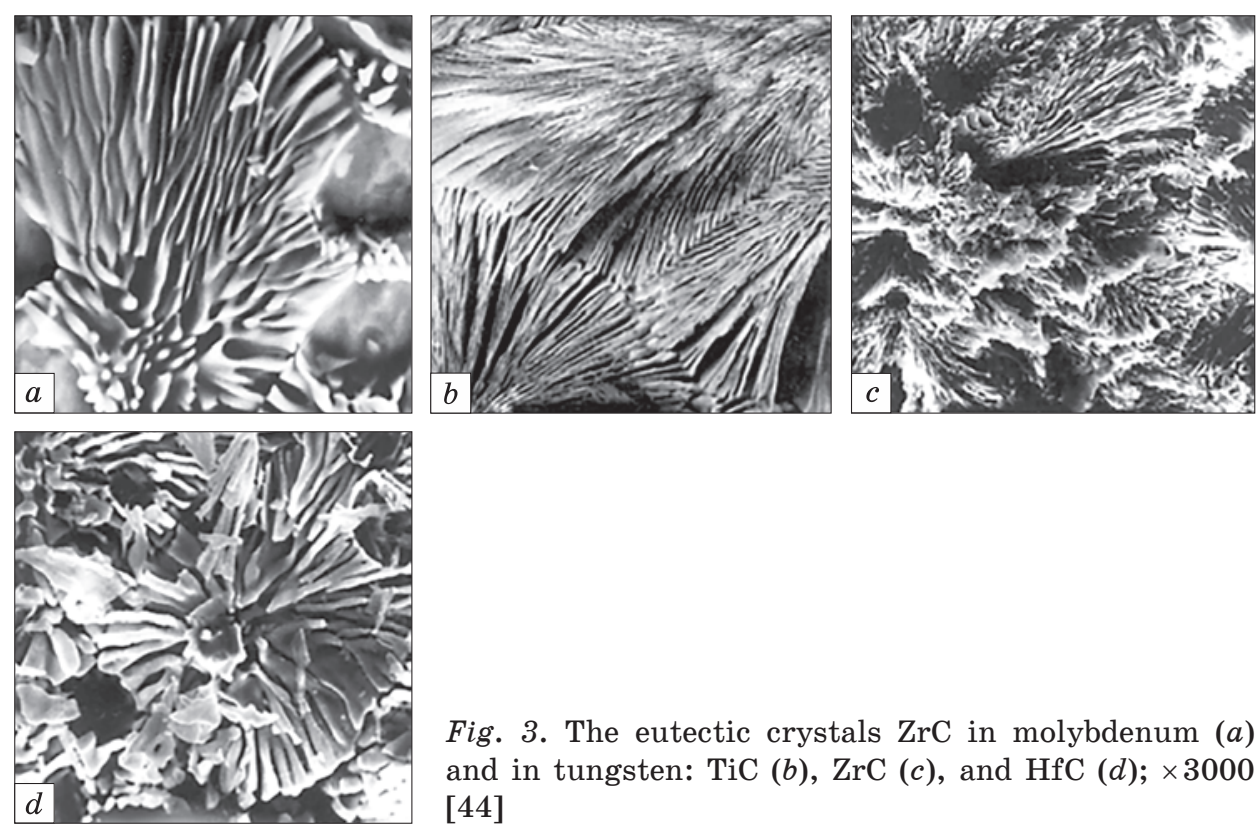

Fig. 3. The eutectic crystals $\mathrm{ZrC}$ in molybdenum $(a)$ and in tungsten: $\operatorname{TiC}(b), \operatorname{ZrC}(c)$, and $\operatorname{HfC}(d) ; \times 3000$ [44]

Hunt-Jackson theory of stationary eutectic growth may be the high temperature gradient in the liquid $G_{L}[47]$.

The studies of phase equilibria and structure of two-phase alloys of chromium with carbides $\mathrm{HfC}, \mathrm{ZrC}, \mathrm{NbC}$, and $\mathrm{TaC}$ were carried out in works [49, 50]. These works were used as the basis for the development of a eutectic alloy with increased characteristics of strength and plasticity in the temperature range $950-1350 \mathrm{~K}$ for moulds for casting hightemperature alloys under pressure [51]. Eutectic composites based on molybdenum were developed based on the study of the structure and properties of the eutectic Mo-ZrC alloy containing 27 vol.\% $\mathrm{ZrC}$ at a temperature of $2520 \mathrm{~K}$ (Fig. 3, a), and eutectic in the Mo-HfC system with a melting point of $2580 \mathrm{~K}$, containing $20.9 \%$ vol. HfC. These alloys have found application as a press tool for hot pressing of optical ceramics [52, 53]. Tungsten-based alloy with carbide hardening was developed based on studying the structure and properties of eutectic alloys of tungsten with titanium, zirconium and hafnium carbides [54, 55]. The tungsten-based alloy was obtained for use in products of space and aviation technology. Figure 3 also shows the structure of tungsten alloys (the tungsten structural component of the eutectic is etched away), containing: 28.6 vol.\% TiC at a melting point of $2970 \mathrm{~K}$ (Fig. 3, b), 50.4 vol. $\%$ ZrC at a melting point of $3060 \mathrm{~K}$ (Fig. 3, c), 93 vol. \% HfC at $3160 \mathrm{~K}$ (Fig. 3, d).

Eutectic metal alloys with refractory carbides have a number of features that provide them high wear resistance: a combination of a soft 
metal base and carbide crystals, which have high hardness and serve as a support during friction. The equable distribution of these hard crystals in the base metal, the reinforcing effect of thin crystals of the carbide phase, gives an increased hardness, strength, and heat resistance to the mentioned eutectic alloys. Thus, the wear resistance of eutectic metal alloys with refractory carbides depends on the volume fraction of the carbide phase in the eutectic. The study of phase equilibria in quasiternary systems of the base metal with two carbides opens up the possibility of obtaining multiphase eutectics, the total fraction of interstitial phases in which can be very significant [44]. It was found that the hardness of alloys could be increased when two carbides represent the carbide component of the eutectic.

Authors of Ref. [29] investigated the influence of the growth rate on the rod spacing selection of the pseudo-binary NiAl-9Mo eutectic alloy in thick samples at higher growth rates to examine the distribution of the eutectic spacings at different growth rates.

\subsection{In situ Aluminium-Matrix Composites}

Currently, a large number of works are devoted to obtain in situ aluminium-matrix composites combining a plastic aluminium matrix with hard reinforcing particles of second phases in an amount of 10-40 vol.\% homogeneously distributed in it [56]. The strength and plasticity of these composites (as well as for most others) are strongly depending largely on the volume fraction, morphology and length scale of the eutectic phase constituents [57-59]. Aluminium-matrix composites find wide application in mechanical engineering (connecting rods, drive shafts, pump cases, brake supports, rotors, etc., are made out of them) instead of heavier steel. However, the introduction of reinforcing particles requires special technologies [60-62] and equipment differing from the serial production of aluminium alloys, which conditions the high cost of composites. An alternative is the principle of production of so-called natural aluminium-matrix CMs, built on the preparation of thin intermetallic phases of eutectic origin in an aluminium matrix [63]. Commonly used reinforcements for $\mathrm{Al}$ and its alloys that can be produced in situ are $\mathrm{Al}_{2} \mathrm{O}_{3}, \mathrm{AlN}$, TiB2, TiC, $\mathrm{ZrB}_{2}$, and $\mathrm{Mg}_{2} \mathrm{Si}$ [64].

$\mathrm{Al}$ matrix with $\mathrm{Al}_{3} \mathrm{Ni}$ fibre eutectic has widely been studied as a model system for deformation and cast application [65, 66]. The eutectic microstructure in this case possesses a high thermal stability at up to $720 \mathrm{~K}$ because the hardness of $\mathrm{Al}_{3} \mathrm{Ni}$ fibre does not decrease significantly [67]. On the other hand, La can additionally enhance the heatresistant properties, corrosion resistance, and vibration resistance of aluminium alloys. The formation of a relatively fine eutectic in the $\mathrm{Al}-$ La system makes its promising for manufacturing of $\mathrm{Al}$ matrix compo- 
sites [68]. For the Al-Ni-La alloys of the Al-rich corner, one can expect the formation of a low-alloyed (Al) solid solution, which coexists with fine $\mathrm{Al}_{3} \mathrm{Ni}$ and $\mathrm{Al}_{4} \mathrm{La}$ eutectic intermetallics.

Iron also strongly affects the formation of the structure and properties of aluminium-matrix composites. It is known that it is able to form brittle intermetallic inclusions and cracks due to the formation of the deformation mode in the eutectic region, which is actively studied by means of microstructural, fractographic, tomographic, and strength methods of analysis for classical silumins [69-71]. At the same time, the investigation of $\mathrm{Al}-\mathrm{Zn}-\mathrm{Mg}-\mathrm{Ni}-\mathrm{Fe}$ and $\mathrm{Al}-\mathrm{Zn}-\mathrm{Mg}-\mathrm{Ca}-\mathrm{Fe}$ alloys showed that iron enters the composition of intermetallic phases of eutectic origin (for instance, $\mathrm{Al}_{9} \mathrm{FeNi}$ and $\mathrm{Al}_{10} \mathrm{CaFe}_{2}$ ) with favourable morphology, thereby providing a combination of high mechanical and process properties of the alloy [72-75].

The numerous publications devoted to the hardening effect due to small additives of $\mathrm{Zr}$ and Sc into aluminium alloys has appeared recently [76-81]. It is established that such hardening is caused by the decay of the (Al) supersaturated aluminium solid solution with the simultaneous formation of coherent spherical nanoparticles $\mathrm{Al}_{3} \mathrm{Zr}, \mathrm{Al}_{3} \mathrm{Sc}$, or $\mathrm{Al}_{3}(\mathrm{Zr}, \mathrm{Sc})$ of structural $L 1_{2}$-type in the course of this process. The formation of the (Al) supersaturated aluminium solid solution occurs at the alloy crystallization stage, which makes it possible to exclude highcost quenching. The results of $[82,83]$ also point to the possibility of such hardening in $\mathrm{Al}-\mathrm{Ni}$ and $\mathrm{Al}-\mathrm{Ca}$ eutectic alloys. Authors of Ref. [84] analysed $\mathrm{Al}-\mathrm{Ca}-\mathrm{Ni}-\mathrm{La}(-\mathrm{Fe})$-based system and investigated the precipitation hardening upon alloying with small zirconium and scandium additives (with their summary content up to 0.3 wt. $\%$ ).

Authors of Ref. [85] suggested the existence of two invariant rections: eutectic $L \rightarrow(\mathrm{Al})+\mathrm{Al}_{4} \mathrm{La}+\mathrm{Al}_{3} \mathrm{Ni}$ and peritectic $L+\mathrm{Al}_{9} \mathrm{NiLa}_{2} \rightarrow$ $\rightarrow \mathrm{Al}_{4} \mathrm{La}+\mathrm{Al}_{3} \mathrm{Ni}$ with a previously undescribed ternary compound. Microscopic analysis revealed that the most promising structure with the finest eutectic is formed in alloys with a total $\mathrm{Ni}$ and La content of about 10-12 wt.\% (with a lanthanum excess of up to 1.7 times). The high strength (UTS about $250 \mathrm{MPa}$, YS $200 \mathrm{MPa}$ ) and acceptable ductility $(3.0 \%)$ for the promising composite $\mathrm{Al}_{7} \mathrm{La}_{4} \mathrm{Ni}$ alloy result from the forming ultrafine eutectic structure.

\subsection{In situ Composites Based on the Eutectic System}

The $\mathrm{Cu}-7 \mathrm{Cr}-0.07 \mathrm{Ag}$ alloys were prepared by casting and directional solidification, from which deformation processed in situ composites were prepared by thermo-mechanical processing [86]. The second-phase $\mathrm{Cr}$ grains of the directional solidification $\mathrm{Cu}-7 \mathrm{Cr}-0.07 \mathrm{Ag}$ in situ composite were parallel to the drawing direction and were finer that led to a higher tensile strength and a better combination of properties. 
In addition, many works are devoted to the study of a natural composite material based of the $\mathrm{Nb}-\mathrm{Si}$ eutectic [87-91]. The high melting temperature and reactivity of niobium alloys lead to their active interaction with most refractory materials. A natural composite structure consisting of parallel cellular layers of a b.c.c. niobium solid solution and a reinforced niobium silicide phase $\mathrm{Nb}_{5} \mathrm{Si}_{3}$ with a hexagonal structure [90].

The materials of $\mathrm{BaTiO}_{3}-\mathrm{CoFe}_{2} \mathrm{O}_{4}$ eutectic system have large electric striction and magneto striction, respectively. Van den Boomgaard et al. [92] have investigated the directional solidification of this system and shown that it is possibly applicable for new devices. Application of this system will be achieved by the combination of magnetic and electric properties (magnetoelectric effect) through strain, a common property of the two oxides. The interface between the two oxides is important for the production of the magneto electric effect, because strain propagates through the interface and the bonding at the interface affects the efficiency of this effect. The microstructure of the eutectic consist grains of lamellar or fibrous morphology. Two types of crystal structures of $\mathrm{BaTiO}_{3}$ were observed for different growth conditions [93]. The interface has misfit dislocations due to the accommodation of lattice mismatch.

Sahm and Killias [94] showed that a fibrous eutectic with Co fibres embedded in an Au-matrix can be obtained at $G / v \geq 2 \cdot 10^{5} \mathrm{deg} / \mathrm{cm}^{2}$, where $G$ is temperature gradient and $v$ is growth velocity. Inter-fibre spacing $2 R$ can be described by $R^{2} v=1.2 \cdot 10^{-11} \mathrm{~cm}^{3} / \mathrm{s}$. Fibre to blade transitions have been found over the entire range of growth velocities employed, i.e. between $10^{-5}$ and $10^{-2} \mathrm{~cm} / \mathrm{sec}$ and are thought to be due to local growth perturbations. Composite growth under the influence of a magnetic field produces two effects: an orienting effect and a shape and size modification. The shape and size modification, which results in thick and segmented caterpillar-like Co fibres, appears to be independent of growth rate (within the limits indicated above), occurs mainly in cell boundaries at all compositions, including hypoeutectic ones, and is thought to be due to a field induced enhancement of local temperature gradients.

Hunt and Jackson [95] shared binary eutectics into two broad grops, namely, regular (non-faceted/non-faceted) and anomalous (faceted/nonfaceted). Later it was shown that further useful subdivisions into distinct structural types could be made by consideration of the entropy of solution and the volume fraction $\left(V_{f}\right)$ of the minor phase [96-98]. Subsequently, the mechanical properties of that group of anomalous eutectics, for which $V_{f} \approx 6$ to $18 \%$ were examined [99-101] as part of a continuing broader examination of eutectic composites. Of these, the $\mathrm{Cd}-$ $\mathrm{Zn}$ eutectic has the appropriate volume fraction, $18 \%$ by volume of aligned $\mathrm{Zn}$ lamellae in a $\mathrm{Cd}$ matrix and information is available on the 
structure [102-104] and compressive properties [105] of this eutectic. In addition, both $\mathrm{Cd}$ and $\mathrm{Zn}$ have an h.c.p. structure with a c/a ratio higher than the ideal and the eutectic was expected to behave as a single-phase material, so far as, the mode of deformation is concerned. It should be noted that directional solidification of off-eutectic alloys has shown that aligned fully eutectic structures can be produced either at a high ratio of temperature gradient to a growth rate $(G / R)[106,107]$, or by employing high growth rates [108]. In this way, the volume fraction of the reinforcing phase can be varied simply by growing off-eutectic compositions at favourable growth conditions. Authors of Ref. [109] showed that the $\mathrm{Cd}-\mathrm{Zn}$ eutectic has been directionally solidified at rates of 2.9 to $4000 \mathrm{~mm} / \mathrm{h}$. Its lamellar microstructure was replaced by a cellular structure at growth rates greater than $400 \mathrm{~mm} / \mathrm{h}$. The interlamellar spacings and cell size decreased within creasing growth rates.

As one of the semiconductor-metal eutectic (SME) composites, $\mathrm{Si}-\mathrm{TaSi}_{2}$ eutectic composite has many characters such as the high melting point of $\mathrm{TaSi}_{2}$ material, the large density of $\mathrm{TaSi}_{2}$ fibres incorporated into the $\mathrm{Si}$ matrix, three-dimensional array of Schottky junctions grown in the composite spontaneously [110]. So, it is an ideal candidate for field emission array cathodes. The $\mathrm{Si}-\mathrm{TaSi}_{2}$ eutectic in situ composite, which has highaligned and uniformly distributed $\mathrm{TaSi}_{2}$ fibres in the Si matrix, can be obtained when the solidification rate changes from 0.3 to $9.0 \mathrm{~mm} / \mathrm{min}$. As the solidification rate is increased, both the fibres' diameter and the interrod spacing are decreased, while the fibres' density and the volume fraction are increased. Moreover, the transition from a planar interface to cellular interface and then to planar interface morphologies with increasing velocity is observed with the zero power method.

In Ref. [111], authors investigated the nickel-boron quasi-eutectic system. The choice of this system is due to the fact that the volume fraction of the boride phase in it is very high ( $75-78$ vol.\%). The conditions for various stages of solidification and formation of a controlled structure in nickel alloys with a high volume content of the boride phase have been determined. The considered principle of the natural formation of phase components during isotropic and directional crystallization shows that it is precisely in the process of obtaining oriented anisotropic materials that it is possible to provide a given structure and special properties.

\subsection{In situ Composites Obtained upon Diffusion Change of Concentration}

Chemical-heat treatment at a constant temperature promotes multiphase transformations for iron alloys. Phase transformations in this case are stimulated by diffusion change of concentration. In a series of works 
Fig. 4. Composite structure of austenite-carbide colonies of $\mathrm{Fe}-\mathrm{W}$ system after chemical heat treatment: $a$ $\times 500$ [124], $b-$ scanning electron microscopy; $\times 1000$ [122]
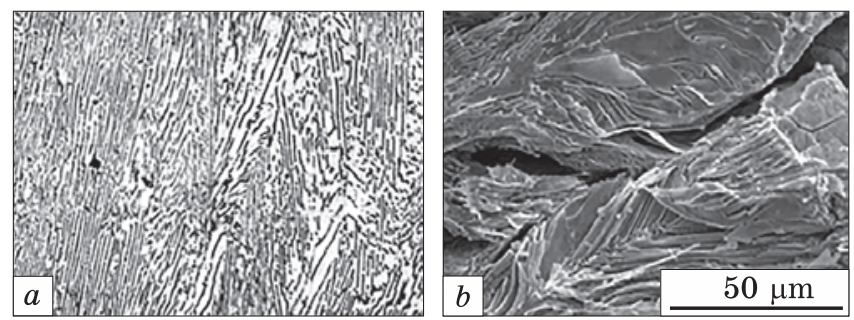

[112-124], the regularities of phase and structural transformations during a diffusional change in carbon composition are considered. The condition for the implementation of transformations of this type is the presence of multiphase regions on the isothermal state diagram and the passage of the composition of the alloy through these regions, which varies in carbon concentration [112]. The eutectoid transformation is carried out by isothermal carburization of ferritic alloys of iron with carbide-forming elements. A joint directed growth of austenite and carbide occurs during carburization of ferritic iron alloys containing carbide-forming $\alpha$-stabilizers, which contributes to the formation of a natural austenite-carbide composite (Fig. 4). The joint growth of these phases is possible if the composition of the ferrite subjected to carburization corresponds to the three-phase equilibrium ferrite-austenitecarbide at the carburizing temperature. The conversion is accompanied by a redistribution of alloy components between the transformation products. As a result, a regular plate or rod austenitic carbide colonies growth is established [113-115]. The colonies grow mainly directed in the direction of carbon flow. Composite growth of austenite-carbide colonies was observed during carburizing of binary alloys $\mathrm{Fe}-\mathrm{W}, \mathrm{Fe}-\mathrm{Mo}$, $\mathrm{Fe}-\mathrm{Cr}, \mathrm{Fe}-\mathrm{V}, \mathrm{Fe}-\mathrm{Ti}$ [116-119]. The mechanism of cooperative transformation during diffusion change of carbon content is similar to eutectic or eutectoid transformations. The reaction proceeds in the opposite direction carried out by peritectoid mechanism at decarburization [120].

The phase and structural changes of $\mathrm{Fe}-\mathrm{W}-\mathrm{Cr}$ and $\mathrm{Fe}-\mathrm{Mo}-\mathrm{Cr}$ alloys in the process of the carburization were researched [112, 121, 123, 124]. The four-phase equilibrium $\alpha+\gamma+M e_{6} \mathrm{C}+M e_{23} \mathrm{C}_{6}(M e$ is a metal) is invariant in $\mathrm{Fe}-\mathrm{W}-\mathrm{Cr}$ and

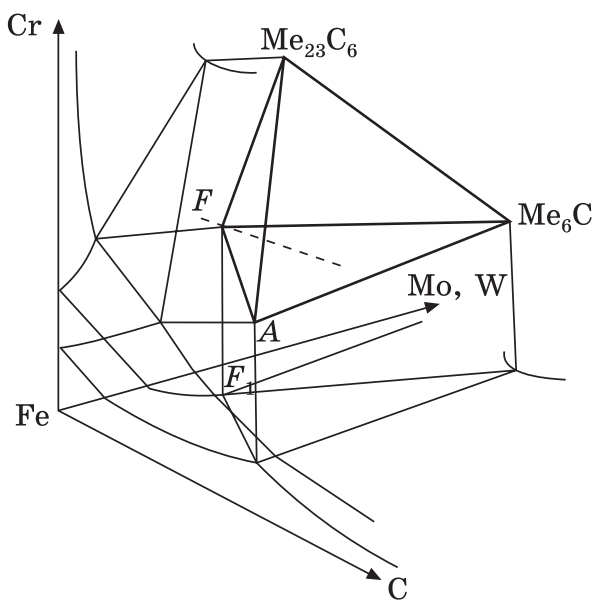

Fig. 5. The section of the phase diagram of $\mathrm{Fe}-(\mathrm{W}, \mathrm{Mo})-\mathrm{Cr}-\mathrm{C}$ [124] 

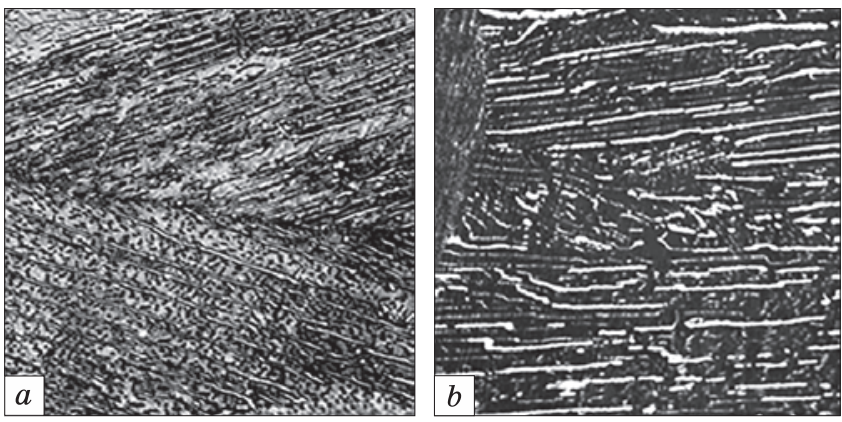

Fig. 6. Compositional structure of $A-M e_{6} \mathrm{C}-$ $M e_{23} \mathrm{C}_{6}$ colonies: $(a)$ system $\mathrm{Fe}-\mathrm{Mo}-\mathrm{Cr}$, $(b)$ system $\mathrm{Fe}-\mathrm{W}-\mathrm{Cr} ; \quad \times 400$ [121]

$\mathrm{Fe}-\mathrm{Mo}-\mathrm{Cr}$ alloys at constant temperature during carburizing. The condition for the joint growth of austenite and carbides is the correspondence of the initial concentration of the matrix alloy to the equilibrium concentration of the $\alpha$-phase in the four-phase region located in the corner of the conoidal pyramid (Fig. 5). The decomposition of ferrite into three phases, namely, austenite and two carbides, is possible. There is a composite material, namely, austenitic matrix, reinforced with two types of carbides (Fig. 6). According to the x-ray microanalysis data, large plates in both alloys are $M e_{23} C_{6}$ carbide with thin $M e_{6} C$ carbide fibres located between them [124].

\section{Conclusions}

The in situ composite material is a trend in modern materials science. It is possible to obtain predefined mechanical and physical properties in the production of in situ composite. The in situ composite material is produced in one-step from an appropriate starting alloy, thus avoiding the difficulties inherent in combining the separate components as in a typical composite processing. Controlled unidirectional solidification of a eutectic alloy is a classic example of in situ processing. Unidirectional solidification of a eutectic alloy can result in one phase being distributed in the form of fibres or ribbon in the other. The relationship between the interface undercooling $\Delta T$, the growth rate $V$ and the eutectic spacing $\lambda$ was presented. The effect of undercooling $\Delta T$ vs. eutectic spacing for a given growth rate $V$ was analysed. An increase in the performance characteristics of composites is largely determined by an understanding of the internal physical processes occurring both in the matrix and strengthening phases and at the interphase boundaries during the solidification of alloys.

The eutectic alloys of transition metals with interstitial phases as their basis, e.g., with carbides of high-melting-point metals IV(A)-V(A) of the subgroup of the Periodic table with high values of free energy of formation, melting point, hardness, modulus of elasticity, and inert to 
the metal-based alloy have high characteristics of heat resistance, hot strength, wear resistance, capable to work at temperatures above 1300 $\mathrm{K}$. The structure of such eutectic alloys provides them the properties of a natural composite, in which the metal base is reinforced with dispersed carbide crystals. The study of a wide range of systems of various types (metal-metal, metal-semiconductor, metal-intermetallic, and intermetallic-intermetallic) made it possible to establish some general laws of the formation of the composite structure.

Chemical-heat treatment at a constant temperature promotes multiphase transformations for iron alloys. The transformations are caused by diffusion change of concentration. The mechanism of cooperative transformation during diffusion change is similar to eutectic or eutectoid transformations.

\section{REFERENCES}

1. A. Ghadi, M. Soltanieh, H. Saghafian, and Z. Yang, Surf. Coating. Technol., 289: 1 (2016); https://doi.org/10.1016/j.surfcoat.2016.01.048

2. D. Miracle, Compos. Sci. Technol., 65: 2526 (2005); https://doi.org/10.1016/j.compscitech.2005.05.027

3. H. Cao, X. Donga, Z. Pan, X. Wu, Q. Huang, and Y. Pei, Materials \& Design, 100: 223 (2016); https://doi.org/10.1016/j.matdes.2016.03.114

4. D. Casellas, J. Caro, S. Molas, J.M. Prado, and I. Valls, Acta Mater., 55: 4277 (2007); https://doi.org/10.1016/j.actamat.2007.03.028

5. Y.K. Jeong, Y.H. Choa, and K. Niihara, J. Am. Ceram. Soc., 81: 1453 (1998); https://doi.org/10.1111/j.1151-2916.1998.tb02503.x

6. J. Zhu, L. Zhong, Y. Xu, S. Zhang, and Z. Lu, Vacuum, 168: 108862 (2019); https://doi.org/10.1016/j.vacuum.2019.108862

7. A.A. Minaev, O.T. Alimova, and M.S. Grishanova, Materials of the 77th Int. Sci.-Tech. Conf. 'Avtomobile- $i$ Traktorostroenie $v$ Rossii: Prioritety Razvitiya i Podgotovka Kadrov'. Sektsiya 6 'Mashiny i Tekhnologii Zagotovitel'nogo Proizvodstva' (Moscow: MGTU 'MAMI': 2012), p. 28 (in Russian).

8. R. Elliott, Eutectic Solidification Processing: Crystalline and Glassy Alloys, (London: Butterworth-Heinemann: 1983), 378 p.

9. F.L. Kennard, R.C. Bradt, and V.S. Stubican, J.Am.Ceram. Soc., 59: 160 (1976); https://doi.org/10.1111/j.1151-2916.1976.tb09457.x

10. I. Bogomol, T. Nishimura, O. Vasylkiv, Y. Sakka, and P. Loboda, J. Alloys and Compd., 509: 6123 (2011);

https://doi.org/10.1016/j.jallcom.2011.02.176

11. I. Bogomol, T. Nishimura, O. Vasylkiv, Y. Sakka, and P. Loboda, J. Alloys and Compd., 485: 677 (2009);

https://doi.org/10.1016/j.jallcom.2009.06.044

12. I. Bogomol, S. Grasso, T. Nishimura, Y. Sakka, P. Loboda, and O. Vasylkiv, Ceram. Int., 38: 3947 (2012);

https://doi.org/10.1016/j.ceramint.2012.01.048

13. I. Bogomol, P. Badica, Y.Q. Shen, T. Nishimura, P. Loboda, and O. Vasylkiv, J. Alloys and Compd., 570: 94 (2013);

https://doi.org/10.1016/j.jallcom.2013.03.084 
14. D. Demirskyi and Y. Sakka, J.Am. Ceram. Soc., 97: 2376 (2014); https://doi.org/10.1111/jace.13083

15. D. Demirskyi and Y. Sakka, J. Ceram. Soc. Jpn., 123: 33 (2015); https://doi.org/10.2109/jcersj2.123.33

16. D. Demirskyi, Y. Sakka, and O. Vasylkiv, J. Asian Ceram. Soc., 3: 369 (2015); https://doi.org/10.1016/j.jascer.2015.08.001

17. D. Demirskyi, Y. Sakka, and O. Vasylkiv, J. Ceram. Soc. Jpn., 123: 1051 (2015); https://doi.org/10.2109/jcersj2.123.1051

18. D. Demirskyi, Y. Sakka, and O. Vasylkiv, J. Am. Ceram. Soc., 99: 2436 (2016); https://doi.org/10.1111/jace.14235

19. S.S. Ordan'yan, A.I. Dmitriev, K.T. Bizhev, and E.K. Stepanenko, Sov. Powder Metall. Met. Ceram., 26: 834 (1987).

20. K.K. Chawla, Composite Materials. Science and Engineering (New York: Springer-Verlag: 1998);

https://doi.org/10.1007/978-1-4757-2966-5

21. L.E. Murr, Handbook of Materials Structures, Properties, Processing and Performance (Springer International Publishing Switzerland: 2015), p. 419; https://doi.org/10.1007/978-3-319-01815-7_24

22. R.W. Hertzberg, Fiber Composite Materials (Ohio: ASM, Metals Park, 1965), p. 77.

23. J.F. Li and Y.H. Zhou, Acta Mater., 53: 2351 (2005);

https://doi.org/10.1016/j.actamat.2005.01.042

24. S.M. Li, Q.R. Quan, X.L. Li, and H.Z. Fu, J. Cryst. Growth, 314: 279 (2011); https://doi.org/10.1016/j.jcrysgro.2010.10.164

25. A. Parisi and M. Plapp, Acta Mater., 56: 1348 (2008); https://doi.org/10.1016/j.actamat.2007.11.037

26. C.J. Cui, J. Zhang, H.J. Su, L. Liu, and H.Z. Fu, J. Cryst. Growth, 311: 2555 (2009); https://doi.org/10.1016/j.jcrysgro.2009.02.014

27. A.E. Ares, S.F. Gueijman, and C.E. Schvezov, J. Cryst. Growth, 14: 2154 (2010); https://doi.org/10.1016/j.jcrysgro.2010.04.040

28. K.A. Jackson and J.D. Hunt, Trans. Metal. Soc. AIME, 236: 1129 (1966).

29. J. Zhang, J. Shen, Z. Shang, Z. Feng, L. Wang, and H. Fu, J. Cryst. Growth, 329: 77 (2011); https://doi.org/10.1016/j.jcrysgro.2011.06.049

30. Y.X. Zhuang and X.M. Zhang, Sci. Tech. Adv. Mater., 2: 37 (2001); https://doi.org/10.1016/S1468-6996(01)00023-7

31. J.C. Liu and R. Elliott, Met. Trans. A, 26: 471 (1995); https://doi.org/10.1007/BF02664683

32. R. Trivedi, J.T. Mason, J.D. Vercheven, and W. Kurz, Met. Trans. A, 22: 2523 (1991); https://doi.org/10.1007/BF02665018

33. V. Seetharaman and R. Trivedi, Met. Trans. A, 19: 2955 (1988); https://doi.org/10.1007/BF02647722

34. J.D. Hunt and K.A. Jackson, Trans. Metal. Soc. AIME, 236: 843 (1966).

35. J. Teng, S. Liu, and R. Trivedi, Acta Mater., 56: 2819 (2008); https://doi.org/10.1016/j.actamat.2008.02.011

36. M. Serefoglu and R.E. Napolitano, Acta Mater., 56: 3862 (2008); https://doi.org/10.1016/j.actamat.2008.02.050

37. J.D. Livingston, Composites, 4: 70 (1973);

https://doi.org/10.1016/0010-4361(73)90752-0 
38. K. Hirano and Q. Koculi, 103-th Annual Meeting Exposition the American Ceramic Society Bulletin (Indianapolis, USA: 2001), p. 1304.

39. V.V. Podolinskiy, Metallofiz. Noveishie Tekhnol., 1: 18 (1996) (in Russian).

40. V.M. Azhazha, V.E. Semenenko, and P.N. Vjugov, Proceedings of ISPM-8, (Kharkiv: 2003), p. 27.

41. V.E. Semenenko and N.N. Pilipenko, VANT: Ser. 'Vakuum, Chistyye Materialy, Sverkhprovodniki', 25: 117 (2003) (in Russian).

42. O. Hiroshi, Technol. Repts. Tohoki Univ., 67: 67 (2002).

43. Yu.P. Kurilo, A.I. Somov, and A.S. Tortika, Fizika Metallov i Metallovedenie, 34: 1291 (1972) (in Russian).

44. G.P. Dmitrieva, Metallofiz. Noveishie Tekhnol., 38: 1407 (2016);

https://doi.org/10.15407/mfint.38.10.1407

45. M.A. Tikhonovskiy, VANT: Ser. 'Vakuum, Chistyye Materialy, Sverkhprovodniki', 6: 115 (2004) (in Russian).

46. M.A. Tikhonovskiy, A.I. Somov, and V.E. Semenenko, Materials of the 1st allU.S.S.R. Conf. 'Zakonomernosti Formirovaniya Struktury Splavov Evtekticheskogo Tipa' (Dnepropetrovsk: DMeTI: 1979), p. 193.

47. A.I. Somov and M.A. Tikhonovskiy, Evtekticheskie Kompozitsii (Moscow: Metallurgiya: 1975).

48. A.I. Somov, M.A. Tikhonovskiy, and N.F. Andrievskaya, Fizika Metallov i Metallovedenie, 46: 1126 (1978).

49. A.K. Shurin and G.P. Dmitrieva, Metallofizika, 51: 105 (1974) (in Russian).

50. G.P. Dmitrieva, A.N. Rakitskiy, and A.K. Shurin, Konstruktsionnyye Splavy Khroma [Chrome Structural Alloys] (Kiev: Naukova Dumka: 1986) (in Russian).

51. R.A. Alfintseva, V.N. Gridnev, G.P. Dmitrieva, A.N. Rakitskiy, V.I. Trefilov, and A.K. Shurin, Splav na Osnove Khroma [Chromium-Based Alloy]: Authors' Certificate 749116 SSSR (Publ. March 21, 1980) (in Russian).

52. S.F. Burlakov, G.P. Dmitrieva, V.A. Lizunov, V.N. Minakov, L.N. Postnov, V.I. Trefilov, A.P. Tribulkin, and A.K. Shurin, Splav na Osnove Molibdena [Molybdenum-Based Alloy], Authors' Certificate No. 518976 SSSR (Publ. February 27, 1976) (in Russian).

53. S.F. Burlakov, G.P. Dmitrieva, V.A. Lizunov, V.N. Minakov, L.N. Postnov, A.P. Tribulkin, V.I. Trefilov, and A.K. Shurin, Splav na Osnove Molibdena [MolybdenumBased Alloy], Authors' Certificate No. 535876 SSSR (Publ. July 22, 1976) (in Russian).

54. V.A. Balashov, G.P. Dmitrieva, G.G. Kurdyumova, Yu.V. Mil'man, V.M. Postnov, V.I. Trefilov, I.M. Shumilova, and A.K. Shurin, Splav na Osnove Vol'frama [Tungsten-Based Alloy], Authors' Certificate No. 666901 SSSR (Publ. February 15, 1979) (in Russian).

55. G.P. Dmitrieva, A.N. Drachinsky, and A.K. Shurin, Metallofizika, 5: 72 (1983) (in Russian).

56. I.J. Polmear, Light Metals: From Traditional Alloys to Nanocrystals. Fourth Edition (Elsevier-Butterworth-Heinemann: 2005); https://doi.org/10.1016/ B978-0-7506-6371-7.X5000-2

57. A.K. Chaubey, S. Scudino, N.K. Mukhopadhyay, M. Samadi Khoshkhoo, B.K. Mishrac, and J. Eckerta, J. Alloys and Compd., 536: 134 (2012);

https://doi.org/10.1016/j.jallcom.2011.12.075

58. N.A. Belov, E.A. Naumova, and D.G. Eskin, Mater. Sci. Eng. A, 271: 134 (1999); https://doi.org/10.1016/S0921-5093(99)00343-3

59. R. Kakitani, R.V. Reyes, A. Garcia, J.E. Spinelli, and N. Cheung, J. Alloys and Compd., 733: 59 (2018);

https://doi.org/10.1016/j.jallcom.2017.10.288 
60. K. Amouri, Sh. Kazemi, A. Momeni, and M. Kazazi, Mater. Sci. Eng. A, 674: 569 (2016);

https://doi.org/10.1016/j.msea.2016.08.027

61. L. Jianke and L. Chuxuan, Mater. Lett., 206: 95 (2017);

https://doi.org/10.1016/j.matlet.2017.06.129

62. I. Mobasherpour, A.A. Tofigh, and M. Ebrahimi, Mater. Chem. Phys., 138: 535 (2013);

https://doi.org/10.1016/j.matchemphys.2012.12.015

63. Y. Xue, R. Shen, S. Ni, M. Song, and D. Xiao, J. Alloys and Compd., 618: 537 (2015); https://doi.org/10.1016/j.jallcom.2014.09.009

64. S.L. Pramod, S.R. Bakshi, and B.S. Murty, Journal of Materials Engineering and Performance, 24: 2185 (2015);

https://doi.org/10.1007/s11665-015-1424-2

65. N.A. Belov, A.N. Alabin, and D.G. Eskin, Scr. Mater., 50: 89 (2004); https://doi.org/10.1016/j.scriptamat.2003.09.033

66. C. Suwanpreecha, P. Pandee, U. Patakham, and C. Limmaneevichitr, Mater. Sci. Eng. A, 709: 46 (2018);

https://doi.org/10.1016/j.msea.2017.10.034

67. C.S. Tiwary, S. Kashyap, D.H. Kim, and K. Chattopadhyay, Mater. Sci. Eng. A, 639: 359 (2015);

https://doi.org/10.1016/j.msea.2015.05.024

68. Y. Hea, J. Liua, S. Qiub, Z. Denga, J. Zhanga, and Y. Shena, Mater. Sci. Eng. A, 701: 134 (2017); https://doi.org/10.1016/j.msea.2017.06.023

69. I. Bacaicoa, M. Wicke, M. Luetje, F.Zeismann, A. Brueckner-Foit, A. Geisert, and M. Fehlbier, Eng. Fract. Mech., 183: 159 (2017); https://doi.org/10.1016/j.engfracmech.2017.03.015

70. Z. Ma, A.M. Samuel, H.W. Doty, S. Valtierra, and F.H. Samuel, Materials \& Design, 57: 366 (2014); https://doi.org/10.1016/j.matdes.2014.01.037

71. C. Puncreobutr, P.D. Lee, K.M. Kareh, T. Connolley, J.L. Fife, and A.B. Phillion, Acta Mater., 68: 42 (2014);

https://doi.org/10.1016/j.actamat.2014.01.007

72. P.K. Shurkin, A.P. Dolbachev, E.A. Naumova, and V.V. Doroshenko, Tsvetnye Metally, 5: 69 (2018); https://doi.org/10.17580/tsm.2018.05.10

73. P.K. Shurkin, N.A. Belov, T.K. Akopyan, A.N. Alabin, A.S. Aleshchenko, and N.N. Avxentieva, Phys. Met. Metallogr., 118: 896 (2017); https://doi.org/10.1134/S0031918X17070109

74. N.A. Belov, E.A. Naumova, V.V. Doroshenko, and N.N. Avxentieva, Russ. J. Non-Ferrous Metals, 59: 67 (2018); https://doi.org/10.3103/S1067821218010054

75. V.Kh. Mann, A.N. Alabin, A.Yu. Krokhin, A.V. Frolov, and N.A. Belov, Light Metal Age, 73: 44 (2015).

76. K.E. Knipling, R.A. Karnesky, C.P. Lee, D.C. Dunand, and D.N. Seidman, Acta Mater., 58: 5184 (2010);

https://doi.org/10.1016/j.actamat.2010.05.054

77. E. Clouet, A. Barbu, L. Lae, and G. Martin, Acta Mater., 53: 2313 (2005);

https://doi.org/10.1016/j.actamat.2005.01.038 
78. W.W. Zhou, B. Cai, W.J. Li, Z.X. Liu, and S. Yang, Mater. Sci. Eng. A, 553: 353 (2012);

https://doi.org/10.1016/j.msea.2012.05.051

79. C. Booth-Morrison, Z. Mao, M. Diaz, D.C. Dunand, C. Wolverton, and D.N. Seidman, Acta Mater., 60: 4740 (2012);

https://doi.org/10.1016/j.actamat.2012.05.036

80. S. Ikeshita, A. Strodahs, and Z. Saghi, Micron, 82: 1 (2016);

https://doi.org/10.1016/j.micron.2015.12.002

81. W. Lefebvre, F. Danoix, H. Hallem, B. Forbord, A. Bostel, and K. Marthinsen, J. Alloys and Compd., 470: 107 (2009);

https://doi.org/10.1016/j.jallcom.2008.02.043

82. N.A. Belov, K.A. Batyshev, and V.V. Doroshenko, Non-Ferrous Met., 43: 49 (2017);

https://doi.org/10.17580/nfm.2017.02.09

83. N.A. Belov, A.N. Alabin, and D.G. Eskin, Scripta Mater., 50: 89 (2004); https://doi.org/10.1016/j.scriptamat.2003.09.033.

84. T.K. Akopyan, N.V. Letyagin, and M.E. Samoshina, Russ. J. Non-Ferrous Metals, 60: 531(2019);

https://doi.org/10.3103/S106782121905002X

85. T.K. Akopyan, N.A. Belov, E.A. Naumova, and N.V. Letyagin, Materials Letters, 245: 110 (2019);

https://doi.org/10.1016/j.matlet.2019.02.112

86. K. Liu, D. Lu, H. Zhou, Y. Yang, A. Atrens, and J. Zou, J. Mater. Eng. Perform., 22: 3723 (2013); https://doi.org/10.1007/s11665-013-0698-5

87. B.P. Bewlay, M.R. Jackson, and J.A. Sutliffe, Mater. Sci. Eng. A, 192-193, Part 2: 534 (1995); https://doi.org/10.1016/0921-5093(95)03299-1

88. B.P. Bewlay, M.R. Jackson, and H.A. Lipsitt, Metall. Mater. Trans. A, 27: 3801 (1996); https://doi.org/10.1007/BF02595629

89. B.P. Bewlay, M.R. Jackson, and M.F. X. Gigliotti, Intermetallic CompoundsPrinciples and Practice: Progress, Volume 3 (Eds. J.H. Westbro and R.I. Fleicher) (John Wiley \& Sons, Ltd: 2002), Ch. 26, p. 541; https://doi.org/10.1002/0470845856.ch26

90. Yu.A. Bondarenko, A.B. Echin, M.Yu. Kolodyazhnyi, and A.R. Narskii, Russ. Metall., 2017: 1012 (2017); https://doi.org/10.1134/S0036029517120047

91. Yu.A. Bondarenko, A.B. Echin, and M.Yu. Kolodyazhnyi, Russ. Metall., 2017: 461 (2017);

https://doi.org/10.1134/S0036029517060052

92. J. Vandenboomgaard, D.R. Terrell, R.A.J. Born, and H.F.J.I. Giller, J. Mater. Sci., 9: 1705 (1974); https://doi.org/10.1007/BF00540770

93. J. Echigoya, S. Hayashi, and Y. Obi, J. Mater. Sci., 35: 5587 (2000); https://doi.org/10.1023/A:1004857014209

94. P.R. Sahm and H.R. Killias, J. Mater. Sci., 5: 1027 (1970); https://doi.org/10.1007/BF02403273

95. J.D. Hunt and K.A. Jackson, Trans. Met. Soc. AIME, 242: 843 (1966).

96. M.N. Croker, R.S. Findler, and R.W. Smith, Proc. Roy. Soc. A, 335: 15 (1973); https://doi.org/10.1098/rspa.1973.0111 
97. M.N. Croker, M. McParlan, D. Barager, and R.W. Smith, J. Cryst. Growth, 29: 85 (1975); https://doi.org/10.1016/0022-0248(75)90055-X

98. M.N. Croker, D. Barager, and R.W. Smith, J. Cryst. Growth, 30: 198 (1975); https://doi.org/10.1016/0022-0248(75)90090-1

99. M. Sahoo and R.W. Smith, Met. Sci., 9: 217 (1975); https://doi.org/10.1179/030634575790444874

100. M. Sahoo and R.W. Smith, Can. Met. Q., 15, No. 1: 1 (1976); https://doi.org/10.1179/cmq.1976.15.1.1

101. M. Sahoo, R.A. Porter, and R.W. Smith, J. Mater. Sci., 11: 1125 (1976); https://doi.org/10.1007/BF00737524

102. W.A. Tiller and R. Mrdjenovich, J. Appl. Phys., 34: 3639 (1963); https://doi.org/10.1063/1.1729283

103. B.J. Shaw, Acta Met., 15: 1169 (1967); https://doi.org/10.1016/0001-6160(67)90391-4

104. B. Soutiere and H.W. Kerr, Trans. Met. Soc. AIME, 245: 2595 (1969).

105. F.R. Mollard and M.C. Flemings, Trans. Met. Soc. AIME, 239: 1534 (1967).

106. K.A. Jackson, Trans. Met. Soc. AIME, 242: 1275 (1968).

107. R.M. Jordan and J.D. Hunt, Met. Trans., 2: 3401 (1971); https://doi.org/10.1007/BF02811622

108. H.E. Cline and J.D. Livingston, Trans. Met. Soc. AIME, 245: 1978 (1969).

109. M. Sahoo, R.A. Porter, and R.W. Smith, J. Mater. Sci., 11: 1680 (1976); https://doi.org/10.1007/BF00737524

110. C. Cui, J. Zhang, B. Li, M. Han, L. Liu, and H. Fu, J. Cryst. Growth, 299: 248 (2007); https://doi.org/10.1016/j.jcrysgro.2006.11.248

111. V.E. Semenenko, T.A. Kovalenko, and M.V. Tret'yakov, Visnik KhNU, Seriya Fizichna 'Yadra, Chastynki, Polya', 619: 115 (2004) (in Russian).

112. A.V. Movchan, A.P. Bachurin, and L.G. Pedan, Dopovidi NAN Ukrainy, 7: 104 (2000) (in Russian).

113. K.P. Bunin, V.I. Movchan, and L.G. Pedan, Izv. VUZov. Chernaya Metallurgiya, 2: 123 (1973) (in Russian).

114. K.P. Bunin, V.I. Movchan, and L.G. Pedan, Izv. AN SSSR. Metally, 3: 164 (1975) (in Russian).

115. V.I. Movchan, L.G. Pedan, and V.P. Gerasimenko, MiTOM, 9: 19 (1983) (in Russian).

116. V.I. Movchan, A.V. Movchan, and Yu.S. Dvoryadkin, Problemy Metallurgicheskogo Proizvodstva, 110: 90 (1993) (in Russian).

117. A.V. Movchan, L.G. Pedan, and A.P. Bachurin, Metally, 5: 53 (1999) (in Russian).

118. V.I. Movchan, L.G. Pedan, and V.I. Ivanica, MiTOM, 8: 12 (1990) (in Russian).

119. V.M. Gavrilenko, V.P. Gerasimenko, and V.I. Movchan, Izv. AN SSSR. Metally, 3: 71 (1984) (in Russian).

120. A.V. Movchan, S.I. Gubenko, A.P. Bachurin, and E.A. Chernoivanenko, Stroitel'stvo, Materialovedenie, Mashinostroenie: Sb. Nauch. Trudov, 64: 262 (2012) (in Russian); http://nbuv.gov.ua/UJRN/smmsc_2012_64_46

121. O.V. Movchan and K.O. Chornoivanenko, $X \bar{V}$ Int. Conf. 'Strategiya Yakosti v Promyslovosti i Osviti’ (Dnipro-Varna: 2019), p. 133 (in Ukrainian).

122. S.I. Gubenko, A.V. Movchan, A.P. Bachurin, and E.A. Chernoivanenko, Novyny Nauki Prydniprov'ya, Seriya 'Inzhenerni Nauky', 2: 87 (2012) (in Russian). 
123. A.P. Bachurin, O.V. Movchan, and L.G. Pedan, MTOM, 1-2: 18 (2001) (in Ukrainian).

124. O.V. Movchan and K.O. Chornoivanenko, Metallurgical and Ore Mining Industry, 5-6: 76 (2019) (in Ukrainian); https://doi.org/10.34185/0543-5749.2019-5-6-76-83

Received 25.09.2020; in final version, 29.01.2021

\section{О.В. Мовчан, К.О. Чорноіваненко}

Національна металургійна академія України, пр. Гагаріна, 4, 49600 Дніпро, Україна

\section{ПРИРОДНІ (IN SITU) комПОзИТИ: ОГЛЯД}

Представлено огляд робіт в області вивчення технологій одержання, закономірностей формування структури та властивостей природніх (in situ) композитів. Головною перевагою природніх (in situ) композитів е термодинамічна стабільність їхнього складу та когерентність (спряженість) гратниць контактувальних фаз. Все це забезпечує композиту високий рівень фізико-механічних властивостей. Показано, що композиційні матеріяли цього типу утворюються в процесі спрямованих фазових перетворень, таких як евтектична кристалізація, евтектоїдний розпад тощо, що спричинено температурним градієнтом, а також як наслідок дифузійної зміни складу. Сформульовано умови зростання природніх (in situ) композитів. В роботі розглянуто механізми зростання композиційних структур евтектичного типу. Вказано чинники, що впливають на морфологію структур евтектичного типу. Розглянуто технологічні прийоми, які уможливлюють одержання матеріялів з наперед заданими властивостями, в яких розмір, об'ємний вміст і просторове розташування фаз характерні для природніх (in situ) композитів. В роботі наведено велику кількість прикладів природніх (in situ) композитів: від легкотопких стопів на основі $\mathrm{Bi}$ та до тяжкотопких евтектик на основі Мо та W (Bi-MnBi, $\mathrm{Cd}-\mathrm{Zn}, \mathrm{Al}-\mathrm{Al}_{3} \mathrm{Ni}, \mathrm{Al}-\mathrm{Al}_{4} \mathrm{La}, \mathrm{Al}-\mathrm{Al}_{10} \mathrm{CaFe}_{2}, \mathrm{Al}-\mathrm{Al}_{9} \mathrm{FeNi}, \mathrm{Al}-\mathrm{Al}_{3} \mathrm{Zr}, \mathrm{Al}-$ $\mathrm{Al}_{3} \mathrm{Sc}, \mathrm{Au}-\mathrm{Co}, \mathrm{Si}-\mathrm{TaSi}_{2}, \mathrm{Cr}-\mathrm{HfC}, \mathrm{Cr}-\mathrm{ZrC}, \mathrm{Cr}-\mathrm{NbC}, \mathrm{Cr}-\mathrm{NbC}, \mathrm{Cr}-\mathrm{TaC}, \mathrm{Nb}-\mathrm{Nb}_{5} \mathrm{Si}_{3}$, $\mathrm{Mo}-\mathrm{ZrC}, \mathrm{Mo}-\mathrm{HfC}, \mathrm{W}-\mathrm{TiC}, \mathrm{W}-\mathrm{ZrC}, \mathrm{W}-\mathrm{HfC}$ тощо). Розглянуто процеси й аспекти структуроутворення. Розглянуто вплив додаткового легування на структуру та властивості композитних матеріялів евтектичного типу в подвійних системах, а також особливості структуроутворення потрійних колоній у композиті.

Ключові слова: композит, евтектика, спрямоване затвердіння, дифузійна зміна складу, структуроутворення. 